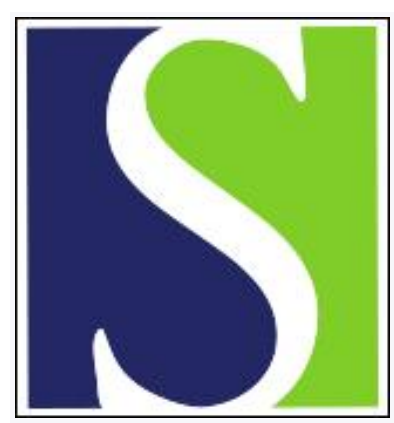

Scand J Work Environ Health 1994;20(6):466-467

https://doi.org/10.5271/sjweh.1373

Issue date: 01 Dec 1994

Sex ratio of offspring as a criterion of occupational hazard, with reference to welding.

by James WH

This article in PubMed: www.ncbi.nlm.nih.gov/pubmed/7701293

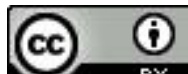


Scand J Work Environ Health 1994;20:466-7

\section{Sex ratio of offspring as a criterion of occupational hazard, with reference to welding}

Concern has been expressed about the fertility of men occupationally exposed to heat $(1,2)$, for example, welders $(3,4)$. Such suspicion is supported by the significantly high proportion of welders with poor sperm quality (5). This finding has been replicated by Bonde (6) who noted that sperm quality declined with increasing exposure and increased after a break in exposure. He also noted low testosterone and high follicular stimulating hormone in welders $(6,7)$. Smith \& Rodriguez-Rigau (8) have reported that such a hormone profile characterizes men with low sperm counts. Thus there is considerable suspicion that welding has a deleterious effect on the male reproductive system.

I have gathered substantial quantities of data to support the hypothesis that the sex of human offspring is partially controlled by the hormone levels of both parents at the time of conception, high levels of gonadotropin and low levels of testosterone favoring the production of daughters $(9-11)$.

There are several male occupations for which offspring sex ratios (proportion male) and hormone profiles have been reported. Table 1 gives such data, and also includes welding. It shows that (in accordance with the hypothesis) the sex ratios for the offspring of divers, drivers, and dibromochloropropane applicators are significantly low. The sex ratio for the offspring of welders is not. However, it is worth noting that, if welding were to diminish the offspring sex ratio by the same degree as that estimated for driving, then a standard power analysis would indicate that, for a $90 \%$ chance of detecting a decrease in gender ratio at the significance level of 0.05 , a sample of more than 40000 children of welders could be needed (21). The sample of Bonde et al (19) numbered 2241. Therefore it would seem prudent at present to keep an open mind on the question of whether welding has some slight effect on the sex ratio of offspring.

Sex ratio as a criterion of occupational hazard has the advantage that it is cheaply and painlessly ascertained, and it is not subject to the measurement errors and biases which characterize assessments of sperm quality and hormone assays. However the present example shows that sex ratio (when based on realistic numbers) may not be an infallible guide to occupational hazard.

\section{References}

1. Rachootin P. Eksogene årsager til infertilitet. Ugeskr Laeger 1980;142:1537-40.

2. Rachootin P, Olsen J. The risk of infertility and delayed conception associated with exposures in the Danish workplace. J Occup Med 1983;25:394-402

3. Bonde JPE. Subfertility in relation to welding: a case referent study among welders. Dan Med Bull 1990; $37: 105-8$

4. Bonde JP, Hansen KS, Levine RJ. Fertility among Danish male welders. Scand J Work Environ Health 1990;16:315-22.

5. Mortensen JT. Risk for reduced sperm quality among metal workers with special reference to welders. Scand J Work Environ Health 1988;14:27-30.

6. Bonde JP. Semen quality and sex hormones among mild steel and stainless steel welders: a cross-sectional study. Br J Ind Med 1990;47:508-14.

7. Bonde JP. Semen quality in welders exposed to radiant heat. Br J Ind Med 1992;49:5-10

8. Smith KD, Rodriguez-Rigau LJ. Laboratory evaluation of testicular function. In: Degroot LJ, Besser GM, Cahill GF, Marshall JC, Nelson DH, Odell WD, et al, editors. Endocrinology. Philadelphia, PA: WB Saunders, 1989:2161-71.

9. James WH. The human sex ratio: part 2. a hypothesis

Table 1. Sex ratios and their $95 \%$ confidence intervals $(95 \% \mathrm{Cl}$ ) for the offspring of men in selected occupations for which poor sperm quality, high gonadotropin levels, or low-testosterone levels, or some combination of the three, have been reported.

\begin{tabular}{lllrrr}
\hline Occupationa & $\begin{array}{l}\text { Reports of poor sperm } \\
\text { quality and/or high } \\
\text { gonadotropin and/or } \\
\text { low testosterone }\end{array}$ & Reports of sex ratios ${ }^{b}$ & $\begin{array}{c}\text { Offspring } \\
(\mathrm{N})\end{array}$ & $\begin{array}{c}\text { Sex } \\
\text { ratio }\end{array}$ & $95 \% \mathrm{Cl}$ \\
\hline $\begin{array}{l}\text { Professional diver } \\
\text { Professional driver }\end{array}$ & $\begin{array}{l}\text { Röckert \& Haglind (12) } \\
\text { Sas \& Szollosi (15) }\end{array}$ & $\begin{array}{l}\text { Lyster (13), Röckert (14) } \\
\text { Dickinson \& Parker (16) }\end{array}$ & 32177 & 0.342 & $0.275-0.409$ \\
Welder & Whorton et al (17) & $\begin{array}{l}\text { Potashnik \& Yanai-Inbar } \\
(18)\end{array}$ & 36 & 0.278 & $0.502-0.512$ \\
& $\begin{array}{l}\text { Mortensen (5), Bonde (6), } \\
\text { Bonde (7) }\end{array}$ & Bonde et al (19) & 2241 & 0.523 & $0.502-0.544$ \\
\hline
\end{tabular}

a Another male occupation with substantial exposure to heat and reportedly associated with a significant excess of daughters is that of carbon setter (20).

- Reported sex ratios for live births in large Caucasian populations vary within very close margins. It is therefore valid to contrast the ratios in this table with expected population values within the range of $0.513-0.515$. 
and a program of research. Hum Biol 1987;59:873900 .

10. James WH. The hypothesized hormonal control of human sex ratio at birth - an update. J Theor Biol 1990; 143:555-64.

11. James WH. The hypothesized hormonal control of mammalian sex ratio at birth - a second update. $J$ Theor Biol 1992;155:121-28.

12. Röckert HOE, Haglid K. Reversible changes in the rate of DNA synthesis in the testes of rats after daily exposure to a hyperbaric environment of air. IRCS Med Sci 1983:11:531.

13. Lyster WR. Altered sex ratio in children of divers. Lancet 1982;2:152.

14. Röckert HOE. Changes in the vascular bed of testes of rats exposed to air at six atmospheres absolute pressure. IRCS Med Sci 1977;5:107.

15. Sas M, Szollosi J. Impaired spermiogenesis as a common finding among professional drivers. Arch Androl $1979 ; 3: 57-60$.

16. Dickinson H, Parker L. Do alcohol and lead change the sex ratio? J Theor Biol. 1994;169:313.

17. Whorton D, Milby TO, Krauss EM, Stubbs HA. Testicular function in DBCP exposed pesticide workers.
J Occup Med 1979;21:161-6.

18. Potashnik G, Yanai-Inbar I. Dibromochloropropane (DBCP): an 8-year evaluation of testicular function and reproductive performance. Fertil Steril 1987;47: $317-23$.

19. Bonde JPE, Olsen JH, Hansen KS. Adverse pregnancy outcome and childhood malignancy with reference to paternal welding exposure. Scand J Work Environ Health 1992;18:169-77.

20. Milham S. Unusual sex ratio of births to carbon setter fathers. Am J Ind Med 1993;23:829-31.

21. Moore DH, Gledhill BL. How large should my study be so that I can detect an altered sex ratio? Fertil Steril 1988;50:21-5.

\section{William H James}

The Galton Laboratory

University College London

Wolfson House

4 Stephenson Way

London NW1 2 HE

United Kingdom 